\title{
Short-term treatment with glucosamine hydrochloride specifically downregulates hypoxia-inducible factor-1 $\alpha$ at the protein level in YD-8 human tongue cancer cells
}

\author{
JEONG-RANG JO* ${ }^{*}$ YU-KYOUNG PARK ${ }^{*}$ and BYEONG-CHURL JANG \\ Department of Molecular Medicine, College of Medicine, Keimyung University, Dalseo-gu 704-701, Republic of Korea
}

Received December 14, 2013; Accepted February 4, 2014

DOI: $10.3892 /$ ijo.2014.2336

\begin{abstract}
Hypoxia-inducible factor-1 (HIF-1) is a tumor angiogenic transcription factor composed of an $\alpha$ and $\beta$ subunit. We investigated the effect of glucosamine hydrochloride $(\mathrm{GS}-\mathrm{HCl})$ on the expression of HIF-1 $\alpha$ and HIF-1 $\beta$ in serum-treated YD-8 human tongue cancer cells. While long-term $(24 \mathrm{~h})$ treatment with $\mathrm{GS}-\mathrm{HCl}$ strongly repressed the expression of HIF- $1 \alpha$ and HIF-1 $\beta$ at both the protein and mRNA levels, short-term (4 h) GS-HCl treatment inhibited HIF-1 $\alpha$ at the protein level. Short-term GS-HCl treatment also decreased phosphorylation of p70S6K and S6, translation-related proteins. However, the results of subsequent pharmacological inhibition and protein stability analyses indicated that HIF-1 $\alpha$ protein downregulation induced by short-term GS-HCl treatment was not through modulation of the mTOR/p70S6K/S6 signaling pathways, the $26 \mathrm{~S}$ proteasomal and lysosomal activities and HIF-1 $\alpha$ protein stability. Importantly, our further analyses identified that HIF-1 $\alpha$ protein downregulation induced by short-term GS-HCl treatment was blunted by exogenous administration of the citric acid cycle metabolites citrate and 2-oxoglutarate, but not the glycolytic end byproducts pyruvate and lactate. These findings demonstrate firstly that short-term GS treatment selectively downregulates HIF-1 $\alpha$ at the protein level in YD-8 cells via interference of production of the citric acid cycle metabolites. It is proposed that short-term $\mathrm{GS}-\mathrm{HCl}$ exposure may be applied for the treatment of oral tumors with high expression of HIF-1 $\alpha$.
\end{abstract}

Correspondence to: Professor Byeong-Churl Jang, Department of Molecular Medicine, College of Medicine, Keimyung University, 1095 Dalgubeol-daero, Dalseo-gu 704-701, Republic of Korea E-mail: jangbc123@gw.kmu.ac.kr; jangbc12@kmu.ac.kr

*Contributed equally

Key words: glucosamine-hydrochloride, hypoxia-inducible factor-1 $\alpha$, 2-oxoglutarate, citrate, YD-8 cells

\section{Introduction}

Glucosamine (GS) is an amino sugar and has been widely used as an alternative regimen for joint-related disease, such as rheumatoid arthritis and osteoarthritis. Many in vivo studies have implicated that GS has preventive actions on adjuvant arthritis in rats (1) and significant symptom-modifying effects on osteoarthritis in human clinical trials (2). In addition, results from many in vitro studies have shown that GS inhibits expression and/or activity of many inflammatory mediators, including cyclooxygenase-2, inducible nitric oxide synthase, matrix metalloproteases and nuclear factor- $\kappa \mathrm{B}(\mathrm{NF}-\kappa \mathrm{B})(3,4)$, which further support its antiinflammatory activity. Moreover, evidence clearly suggests that GS has strong anticancer effects. For instance, it has been previously shown that GS inhibits tumor growth $(5,6)$. We and other investigators also have demonstrated the ability of GS to induce apoptosis in human cancer cells, such as prostate (DU145), breast (MDA-MB-231), leukemia (K562), glioma (U87MG) and tongue (YD-8) (7-12). Moreover, it is suggested that the mechanisms underlying GS-mediated anti-proliferative and pro-apoptotic effect on cancer cells may include translocation of cathepsin D and downregulation of B-cell lymphoma-extra large (8), inhibition of p70S6 kinase (p70S6K) (9) and signal transducer and activator of transcription-3 (STAT-3) (10), induction of autophagy via the stimulation of endoplasmic reticulum (ER) stress (11), and activation of caspases via the intrinsic pathway (12). In recent studies, we and other investigators have also demonstrated the ability of GS to inhibit expression of HIF-1 $\alpha$, a tumor angiogenic transcription factor in $\mathrm{YD}-8$ tongue cancer cells (12) and in DU145 prostate cancer cells (13), which may support its antitumor property.

HIF-1 protein is composed of an $\alpha$ and a $\beta$ subunit (14). In most cells, while expression of HIF- $1 \alpha$ protein is differentially regulated under normoxic and hypoxic condition, HIF-1 $\beta$ protein is constitutively expressed regardless of oxygen tension (15). Indeed, numerous studies have demonstrated that under normoxia HIF-1 $\alpha$ protein is unstable and rapidly destructed via the $26 \mathrm{~S}$ proteasome-dependent protein degradation pathway, but HIF-1 $\alpha$ protein, under hypoxia, is stable and the stable HIF-1 $\alpha$ binds to HIF-1 $\beta$ (16-19). The $\mathrm{HIF}-1 \alpha / \beta$ dimeric complex then localizes to the nucleus where 
the dimeric complex mediates the transcriptional induction of hypoxia responsive element containing genes that encode products involved in the hypoxic adaptation and/or new blood vessel formation (15). However, there is increasing body of evidence suggesting the hypoxia-independent upregulation of HIF-1 $\alpha$ expression. For instance, it is shown that a number of factors, including serum, interleukin-1 $\beta$, insulin, manganese, and ginsenoside-Rg1, induces expression of HIF-1 $\alpha$ through transcriptional and/or translational upregulation in many types of cells under normoxia $(13,20-23)$. Evidence also strongly suggests that activities of many intracellular signaling proteins, such as phosphoinositide 3-kinase, extracellular-regulated protein kinase-1/2, c-jun N-terminal kinase-1, S6, p38 mitogen-activated protein kinase, epidermal growth factor receptor/p70S6K, protein kinase B/mammalian target of rapamycin-p70S6K, and mTOR/p70S6K/S6, are necessary for normoxic induction of HIF-1 $\alpha$ expression in response to extracellular stimuli $(22,24-28)$.

Little is known about regulation of HIF-1 $\alpha$ and HIF-1 $\beta$ expressions by GS in cancer cells. In this study, we investigated whether GS treatment for long-term (24 h) or short-term $(4 \mathrm{~h})$ period differentially regulates expression of HIF-1 $\alpha$ and HIF-1 $\beta$ in serum-treated YD-8 human tongue cancer cells under normoxic condition and if any, determined the molecular and/or cellular mechanisms involved.

\section{Materials and methods}

Materials. RPMI-1640 medium, fetal bovine serum (FBS), and penicillin-streptomycin were purchased from Welgene (Daegu, Korea). Primary antibodies: mouse monoclonal anti-human HIF-1 $\beta$, rabbit polyclonal anti-human p-p70S6K (Santa Cruz Biotechnology, Delaware, CA, USA), rabbit polyclonal anti-human p-S6 (Cell Signaling Technology, Beverly, MA, USA), rabbit polyclonal anti-human p-eIF-2 $\alpha$ (Epitomics, Burlingame, CA, USA), and mouse monoclonal anti-human HIF-1 $\alpha$ (BD Bioscience, San Jose, CA, USA) were purchased from the indicated companies. Secondary antibodies: goat anti-rabbit IgG-HRP and goat anti-mouse IgG-HRP were purchased from Santa Cruz Biotechnology (Santa Cruz, CA, USA). ECL western detection reagents were purchased from Thermo Scientific (Waltham, MA, USA). Bradford reagent was bought from Bio-Rad (Hercules, CA, USA). Plasticware, including 6-well plates, was purchased from SPL Life Sciences (Gyeonggi-do, Korea). Other reagents, including GS-HCl, were purchased from Sigma (St. Louis, MO, USA).

Cell culture. YD-8 human tongue cancer cells (Korean Cell Line Bank, Seoul, Korea) were grown at $37^{\circ} \mathrm{C}$ in a humidified condition of $95 \%$ air and $5 \% \mathrm{CO}_{2}$ in RPMI-1640 supplemented with $10 \%$ heat-inactivated FBS, $100 \mathrm{U} / \mathrm{ml}$ penicillin and $100 \mu \mathrm{g} / \mathrm{ml}$ streptomycin.

Preparation of whole cell lysates. To see the effect of GS-HCl on phospho-specific and/or total expression levels of a variety of cellular proteins, including HIF-1 $\alpha$, HIF-1 $\beta$, p70S6K, S6 and eukaryotic translation initiation factor- $2 \alpha$ (eIF-2 $\alpha$ ), YD-8 cells $\left(0.5 \times 10^{6} / 2 \mathrm{ml} /\right.$ well $)$ were seeded in 6 -well plates the day before $\mathrm{GS}-\mathrm{HCl}$ treatment. Cells were treated without or with different concentrations of $\mathrm{GS}-\mathrm{HCl}$ for 4 or $24 \mathrm{~h}$. Control or
GS-HCl-treated cells were then washed twice with PBS and exposed to cell lysis buffer [50 mM Tris- $\mathrm{HCl}$ (pH 7.4), $150 \mathrm{mM}$ $\mathrm{NaCl}, 0.1 \%$ sodium dodecyl sulfate, $0.25 \%$ sodium deoxycholate, $1 \%$ Triton X-100, 1\% Nonidet P-40, 1 mM EDTA, 1 mM EGTA, proteinase inhibitor cocktail (1X)]. The cell lysates were collected in a $1.5 \mathrm{ml}$ tube and centrifuged for $20 \mathrm{~min}$ at $4^{\circ} \mathrm{C}$ at $12,000 \mathrm{rpm}$. The supernatant was saved and protein concentrations were determined with Bradford reagent.

Western blot analysis. Proteins $(50 \mu \mathrm{g})$ were separated by SDS-PAGE (10\%) and transferred onto nitrocellulose membranes (Millipore, Billerica, MA, USA). The membranes were washed with TBS (10 mM Tris, $150 \mathrm{mM} \mathrm{NaCl})$ supplemented with $0.05 \%$ (vol/vol) Tween-20 (TBST) followed by blocking with TBST containing 5\% (wt/vol) non-fat dried milk. The membranes were incubated overnight with antibodies specific for p-p70S6K (1:2,000), p-S6 (1:2,000), HIF-1 $\alpha$ $(1: 1,000), \operatorname{HIF}-1 \beta(1: 1,000)$, eIF- $\alpha(1: 1,000)$ or actin $(1: 5,000)$ at $4^{\circ} \mathrm{C}$. The membranes were then exposed to secondary antibodies coupled to horseradish peroxidase for $2 \mathrm{~h}$ at room temperature. The membranes were washed three times with TBST at room temperature. Immunoreactivities were detected by ECL reagents. Equal protein loading was assessed by the expression level of actin protein.

Reverse transcription-polymerase chain reaction (RT-PCR). To see the effect of GS-HCl on mRNA expression of HIF-1 $\alpha$, HIF- $1 \beta$ or actin, YD- 8 cells $\left(0.5 \times 10^{6} / 2 \mathrm{ml} /\right.$ well $)$ was seeded in 6 -well plates the day before $\mathrm{GS}-\mathrm{HCl}$ treatment. Cells were treated without or with different concentrations of GS-HCl for 4 or $24 \mathrm{~h}$. Total cellular RNA from control or GS-HCl-treated cells was isolated with the RNAzol-B (Tel-Test, Friendswood, TX, USA). Total RNA ( $3 \mu \mathrm{g}$ ) was reverse transcribed using a random hexadeoxynucleotide primer and reverse transcriptase. Single stranded cDNA was amplified by PCR with the following primers. The sequences of the respective primer are: HIF-1 $\alpha$ sense, 5'-CTCAAAGTCGGACAGCCTCA-3'; HIF-1 $\alpha$ antisense, 5'-CCCTGCAGTAGGTTTCTGCT-3'; HIF-1 $\beta$ sense, 5'-GTG CGCACACATGCTTCTGT-3'; HIF-1 $\beta$ antisense, 5'-CTTTAT GGCCAAGTCTCGGGT-3'; actin sense, 5'-GGTGAAGGTC GGTGTGAACG-3'; actin antisense, 5'-GGTAGGAACACGG AAGGCCA-3'. The PCR conditions applied were: HIF-1 $\alpha, 25$ cycles of denaturation at $95^{\circ} \mathrm{C}$ for $30 \mathrm{sec}$, annealing at $59^{\circ} \mathrm{C}$ for $30 \mathrm{sec}$, and extension at $72^{\circ} \mathrm{C}$ for $30 \mathrm{sec}$; HIF-1 $\beta, 25$ cycles of denaturation at $95^{\circ} \mathrm{C}$ for $30 \mathrm{sec}$, annealing at $56^{\circ} \mathrm{C}$ for $30 \mathrm{sec}$, and extension at $72^{\circ} \mathrm{C}$ for $30 \mathrm{sec}$; actin, 25 cycles of denaturation at $95^{\circ} \mathrm{C}$ for $30 \mathrm{sec}$, annealing at $56^{\circ} \mathrm{C}$ for $30 \mathrm{sec}$, and extension at $72^{\circ} \mathrm{C}$ for $30 \mathrm{sec}$. Expression levels of actin mRNA was used as an internal control to evaluate the relative mRNA expression of HIF-1 $\alpha$ and HIF-1 $\beta$.

Measurement of HIF-1 $\alpha$ protein stability. To determine the stability of HIF-1 $\alpha$ protein in control or GS-HCl-treated YD-8 cells, YD- 8 cells $\left(0.5 \times 10^{6}\right.$ cells in $2 \mathrm{ml} /$ well in a 6 -well plate $)$ were primarily grown in culture medium containing serum (10\% FBS) for $4 \mathrm{~h}$ under normoxic condition to induce high cellular levels of HIF-1 $\alpha$ protein. Cells were then treated for an additional $0.25,0.5$ or $1 \mathrm{~h}$ without or with $\mathrm{GS}-\mathrm{HCl}$ in the presence of $\mathrm{CHX}$, a translation inhibitor, to block ongoing translation. Each time, whole cell lysates were prepared and 


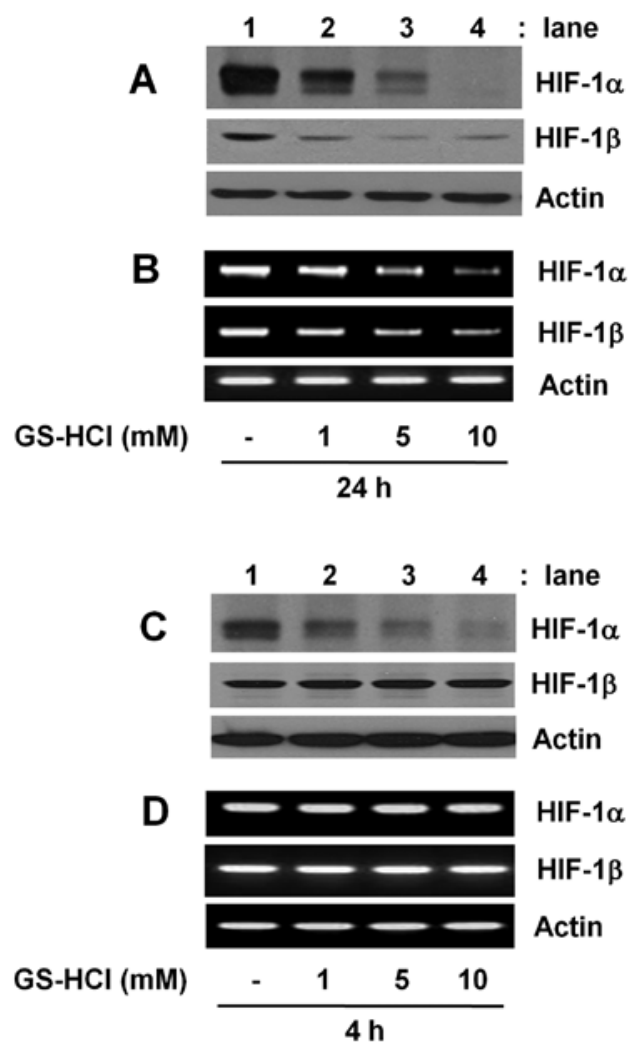

Figure 1. Comparison of the effect of GS-HCl treatment for short-term and long-term period on expression of HIF- $1 \alpha$ and HIF- $1 \beta$ in YD- 8 cells. (A-D) YD-8 cells were treated without or with $\mathrm{GS}-\mathrm{HCl}$ at the indicated doses $(1,5$ or $10 \mathrm{mM})$ for short-term $(4 \mathrm{~h})$ or long-term $(24 \mathrm{~h})$ period. At each time point, whole cell lysates and total RNA were then prepared, and analyzed by (A and C) western blot and (B and D) RT-PCR analysis, respectively. The experiments were carried out under normoxia. Each image in (A), (B), (C) or (D) is a representative of three independent experiments.

subjected to immunoblot analysis for HIF-1 $\alpha$ or actin to measure the amounts of HIF- $1 \alpha$ protein remaining in the cells. Actin was used as an internal control to relatively compare the level of HIF-1 $\alpha$ remaining in the cells.

\section{Results}

Time-differential regulation of HIF-1 $\alpha$ and HIF-1 $\beta$ expressions in $\mathrm{YD}-8$ cells by $\mathrm{GS}-\mathrm{HCl}$. Initially, we investigated whether $\mathrm{GS}-\mathrm{HCl}$ treatment for short-term $(4 \mathrm{~h})$ or long-term ( $24 \mathrm{~h}$ ) period differentially regulates expressions of HIF-1 $\alpha$ and HIF-1 $\beta$ in YD-8 cells grown in culture media containing serum (10\% FBS) under normoxia. As shown in Fig. 1A and B, compared with control (lane 1), long-term GS-HCl treatment led to a concentration-dependent downregulation of HIF-1 $\alpha$ at the both protein and mRNA levels (lanes 2-4). However, there was also a dose-dependent reduction of HIF- $1 \beta$ protein and mRNA expressions by long-term GS-HCl treatment. As shown in Fig. 1C and D, compared with control (lane 1), shortterm GS-HCl treatment also led to a concentration-dependent downregulation of HIF-1 $\alpha$ protein (lanes 2-4). Short-term $\mathrm{GS}-\mathrm{HCl}$ treatment at the doses tested, however, did not affect expression of HIF- $1 \alpha$ mRNA, HIF-1 $\beta$ protein and HIF-1 $\beta$ mRNA. Control actin protein or mRNA expression remained constant under these experimental conditions (Fig. 1).


Figure 2. Effect of short-term GS-HCl treatment on phosphorylation of p70S6K, S6 and eIF-2 $\alpha$ in YD-8 cells. (A) YD-8 cells were treated without or with $\mathrm{GS}-\mathrm{HCl}(10 \mathrm{mM})$ for 2 or $4 \mathrm{~h}$. Whole cell lysates were then prepared, and analyzed by western blot analysis. (B) YD- 8 cells were treated without or with GS-HCl $(10 \mathrm{mM})$ in the absence or presence of rapamycin, an inhibitor of mTOR/p60S6K/S6 signaling pathway for 2 or $4 \mathrm{~h}$. Whole cell lysates were then prepared, and analyzed by western blot analysis. The experiments were carried out under normoxia. Each image in (A) or (B) is a representative of three independent experiments. p-p70S6K, phosphorylated p70S6K; p-S6, phosphorylated S6; p-eIF-2 $\alpha$, phosphorylated eIF-2 $\alpha$.

Short-term GS-HCl treatment induces change of the phosphorylation levels of p70S6K, S6 and eIF-2 $\alpha$, translation-related proteins in YD-8 cells. Considering that short-term GS-HCl treatment inhibits HIF-1 $\alpha$ at protein, but not mRNA, level (Fig. 1C and D), we next determined the effect of short-term $\mathrm{GS}-\mathrm{HCl}$ treatment on activities of translation-related signaling proteins, herein p70S6K, S6 and eIF-2 $\alpha$, in YD-8 cells. As shown in Fig. 2A, in the absence of GS-HCl, there were high levels of phosphorylated p70S6K and S6 while no or weakly phosphorylated eIF- $2 \alpha$ in YD-8 cells cultured for 2 or $4 \mathrm{~h}$ in media containing serum under normoxia (lane 1 or 3 ). Notably, short-term $(2$ or $4 \mathrm{~h})$ treatment with GS-HCl decreased the amounts of phosphorylated p70S6K and S6 but increased the levels of phosphorylated eIF-2 $\alpha$ (lane 2 or 4). Rapamycin is an inhibitor of mTOR kinase complex, a master regulator of protein translation and has been shown to inhibit phosphorylation and activation of the mTOR and its downstream targets, p70S6K and S6 $(26,29)$. Using rapamycin, we next investigated whether HIF-1 $\alpha$ protein downregulation by short-term $\mathrm{GS}-\mathrm{HCl}$ treatment is due to inhibition of mTOR/p70S6K/S6 signals. As shown in Fig. 2B, while short-term (2 or 4 h) GS-HCl treatment that largely blocked S6 phosphorylation (top panel, lane 2 or 5) strongly suppressed HIF-1 $\alpha$ protein expression (middle panel, lane 2 or 5), treatment with rapamycin for 2 or $4 \mathrm{~h}$ that completely inhibited S6 phosphorylation (top panel, lane 3 or 6) had no effect on expression of HIF-1 $\alpha$ protein (middle panel, lane 3 or 6 ). Control actin protein expression remained constant under these experimental conditions (Fig. 2A and B). 

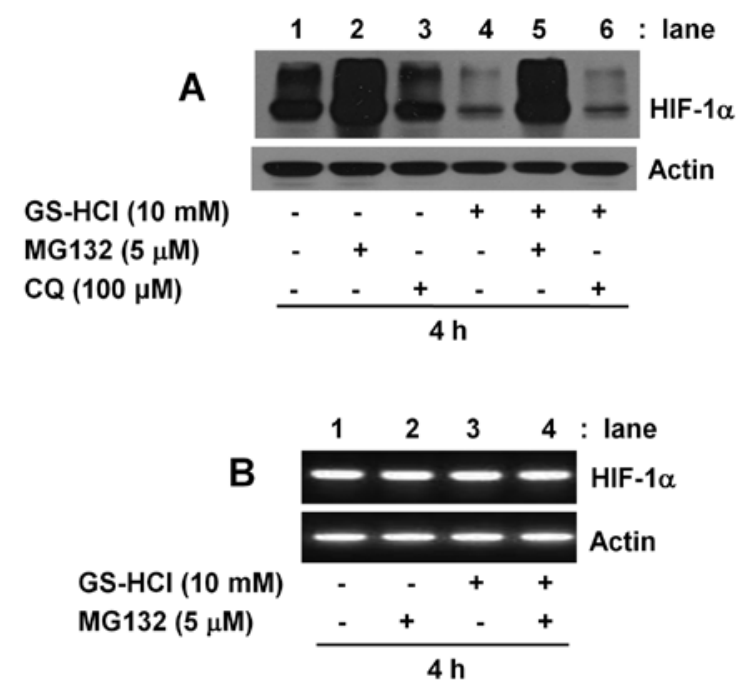

Figure 3. Effect of MG132 or CQ on expression of HIF-1 $\alpha$ in control and GS-HCl-treated YD-8 cells. (A and B) YD-8 cells were treated without or with GS- $\mathrm{HCl}(10 \mathrm{mM})$ in the absence or presence of MG132, the 26S proteasome inhibitor or CQ, the lysosome inhibitor for $4 \mathrm{~h}$. Whole cell lysates and total RNA were then prepared, and analyzed by (A) western blot and (B) RT-PCR analysis, respectively. The experiments were carried out under normoxia. Each image in (A) or (B) is a representative of three independent experiments.

The inhibitory effect of short-term GS-HCl treatment on $H I F-1 \alpha$ protein expression in YD-8 cells is the 265 proteasome- and lysosome-independent. Cellular expression of a protein is largely influenced by the protein degradation. Protein degradation is often mediated through the $26 \mathrm{~S}$ proteosome- and lysosome-mediated proteolytic pathways. Using MG132, the 26S proteosome inhibitor or chloroquine (CQ), the lysosomal inhibitor, we next questioned whether the HIF-1 $\alpha$ protein downregulation induced by short-term $\mathrm{GS}-\mathrm{HCl}$ treatment is linked to the $26 \mathrm{~S}$ proteosome and/or lysosome pathways in YD-8 cells. As shown in Fig. 3A, the inhibitory effect of short-term GS-HCl treatment on HIF-1 $\alpha$ protein expression (lane 4) was largely blocked by MG132 (lane 5), but not CQ (lane 6). However, it was found that single treatment with MG132 for $4 \mathrm{~h}$ was enough to strongly increase expression of HIF-1 $\alpha$ protein (lane 2). Single treatment with $\mathrm{CQ}$ for $4 \mathrm{~h}$ had no enhancing effect on expression of HIF-1 $\alpha$ protein (lane 3). As shown in Fig. 3B, HIF-1 $\alpha$ mRNA expression remained unchanged by $4 \mathrm{~h}$ treatment without or with $\mathrm{GS}-\mathrm{HCl}$ in the absence or presence of MG132 (lanes 1-4). Control actin protein or mRNA expression was not affected under these experimental conditions (Fig. 3A and B).

The inhibitory effect of short-term GS-HCl treatment on $H I F-1 \alpha$ protein expression in YD-8 cells is not due to alteration of HIF-1 $\alpha$ protein stability. Cellular expression of a protein is largely influenced by the protein stability. Cycloheximide $(\mathrm{CHX})$ is a translation inhibitor and has been widely used as a key biochemical agent in determining the stability of a protein. Using CHX, we further determined whether HIF-1 $\alpha$ protein downregulation induced by short-term GS-HCl treatment is associated with change of HIF-1 $\alpha$ protein stability. As shown in Fig. 4, in the presence of $\mathrm{CHX}$, there was a sharp decline of the amounts of HIF-1 $\alpha$ protein remained in YD- 8 cells

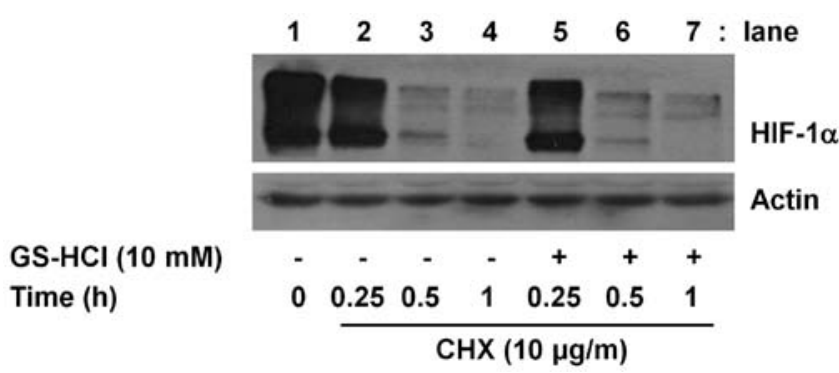

Figure 4. Effect of short-term GS-HCl treatment on $\mathrm{HIF}-1 \alpha$ protein stability in YD-8 cells. YD-8 cells were initially grown in culture medium containing serum (10\% FBS) for $4 \mathrm{~h}$ to highly induce HIF-1 $\alpha$ protein and then treated without or with GS-HCl $(10 \mathrm{mM})$ in the presence of cycloheximide $(\mathrm{CHX})$, a translational inhibitor for additional $0.25,0.5$ or $1 \mathrm{~h}$. At each time point, whole cell lysates were prepared and analyzed by western blot analysis to measure the amounts of HIF-1 $\alpha$ protein remaining in the cells. The experiments were carried out under normoxia. The image is a representative of three independent experiments.

(lanes 2-4), suggesting that when translation is blocked by $\mathrm{CHX}, \mathrm{HIF}-1 \alpha$ protein is unstable and rapidly degraded in the cells. However, the rapid degradation of HIF-1 $\alpha$ protein was not further enhanced or accelerated in the presence of $\mathrm{GS}-\mathrm{HCl}$ at the times tested. Control actin protein expression remained constant under these experimental conditions (Fig. 4).

The inhibitory effect of short-term GS-HCl treatment on $H I F-1 \alpha$ protein expression in YD-8 cells is blunted by exogenous supplementation of the citric acid cycle intermediates (citrate, 2-oxoglutarate), but not the glycolytic end products (pyruvate, lactate).GS is a glucose deprivation mimetic and thus an inhibitor of glycolysis. It is thus suggested that $4 \mathrm{~h}$ exposure of GS into YD-8 cells may interfere with glucose metabolism, which may lead to no or less production of the byproducts of glucose metabolism. Using exogenous supplementation of a number of glucose metabolites, including lactate, pyruvate (the glycolytic end products), citrate and 2-oxoglutarate (the citric acid cycle intermediates), we next investigated whether $\mathrm{HIF}-1 \alpha$ protein downregulation by short-term GS-HCl treatment is linked to the ability of GS-HCl to interfere with glucose metabolism pathway. As shown in Fig. 5A or B, compared with control (lane 1), single administration of pyruvate or lactate did not affect expression of HIF-1 $\alpha$ protein (lane 2). Furthermore, $\mathrm{HIF}-1 \alpha$ protein downregulation by short-term $\mathrm{GS}-\mathrm{HCl}$ treatment (lane 3) was not blocked by addition of pyruvate or lactate (lane 4). Notably, as shown in Fig. 5C, though single administration of citrate did not affect expression of HIF-1 $\alpha$ protein (lane 2), the inhibitory effect of short-term $\mathrm{GS}-\mathrm{HCl}$ treatment on HIF-1 $\alpha$ protein expression (lane 3) was in part blunted by addition of citrate (lane 4). Of further note, as shown in Fig. 5D, compared with control (lane 1), single administration of 2-oxoglutarate largely increased (enhanced) expression of HIF-1 $\alpha$ protein (lane 2 ), HIF-1 $\alpha$ protein downregulation by short-term GS-HCl treatment (lane 3) was not shown in the presence of 2-oxoglutarate (lane 4).

The specificity of short-term $\mathrm{GS}$ - $\mathrm{HCl}$ treatment to inhibit expression of HIF-1 $\alpha$ protein in YD-8 cells. To evauate the specificity, we next compared the effect of short-term $(4 \mathrm{~h})$ 

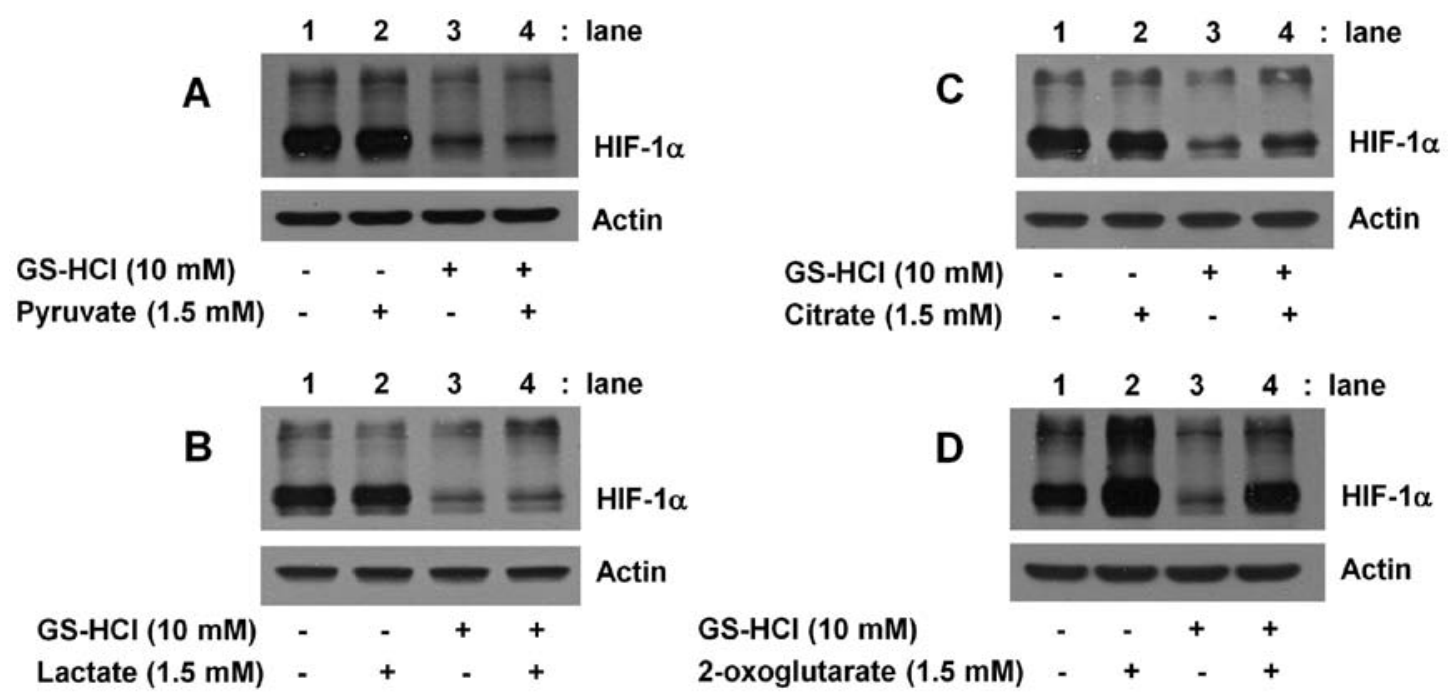

Figure 5. Effect of various glucose metabolites on expression of HIF-1 $\alpha$ protein in control or GS-HCl-treated YD-8 cells. YD-8 cells were treated without or with $\mathrm{GS}-\mathrm{HCl}(10 \mathrm{mM})$ in the absence or presence of various glucose metabolites, including (A) pyruvate (1.5 mM), (B) lactate (1.5 mM), (C) citrate (1.5 mM), and (D) 2-oxoglutarate $(1.5 \mathrm{mM})$ for $4 \mathrm{~h}$. Whole cell lysates were then prepared, and analyzed by western blot analysis. The experiments were carried out under normoxia. Each image is a representative of three independent experiments.

treatment of GS-HCl and other salt form or derivative of GS, herein GS-sulfate or N-acetyl GS, on expression of HIF-1 $\alpha$ protein in YD-8 cells. As shown in Fig. 6, short-term (4 h) treatment with GS-HCl led to strong inhibition of HIF-1 $\alpha$ protein expression (lane 2), but treatment with GS-sulfate or $\mathrm{N}$ acetyl GS for $4 \mathrm{~h}$ did not affect expression of HIF-1 $\alpha$ protein (lane 3 or 4 ).

\section{Discussion}

HIF-1 is a tumor angiogenic transcription factor composed of an $\alpha$ and $\beta$ subunit and is regarded an interesting therapeutic target in cancer biology. Little is known about regulation of HIF-1 $\alpha$ and HIF-1 $\beta$ expressions by GS-HCl in cancer cells. Here, we report for the first time that short-term GS-HCl treatment selectively downregulates HIF-1 $\alpha$ at protein level in YD-8 cells through interference of production of the citric acid cycle intermediates.

Expression of HIF-1 $\alpha$ is regulated at multiple steps, including transcription, translation and/or post-translation $(17,19,22,30,31)$. The present study demonstrates that GS-HCl inhibits expression of HIF-1 $\alpha$ at the protein and mRNA levels in YD-8 cells in the time differentially. We have shown that long-term GS treatment with $\mathrm{GS}-\mathrm{HCl}(10 \mathrm{mM})$ inhibits expression of HIF-1 $\alpha$ at the both protein and mRNA levels in YD-8 cells (Fig. 1A and B), suggesting HIF-1 $\alpha$ transcriptional downregulation. However, considering the present findings that short-term $\mathrm{GS}-\mathrm{HCl}$ treatment inhibits $\mathrm{HIF}-1 \alpha$ at protein level (Fig. 1C), but it does not influence HIF-1 $\alpha$ mRNA expression (Fig. 1D) and protein stability (Fig. 3C) in YD-8 cells, it is likely that short-term GS-HCl treatment represses HIF-1 $\alpha$ protein expression via inhibition of translational process and/or cellular accumulation of the protein. Aforementioned, HIF-1 $\beta$ is shown to be ubiquitously expressed in most types of cells regardless of oxygen tension. We have herein shown that HIF-1 $\beta$ mRNA and protein are substantially expressed in

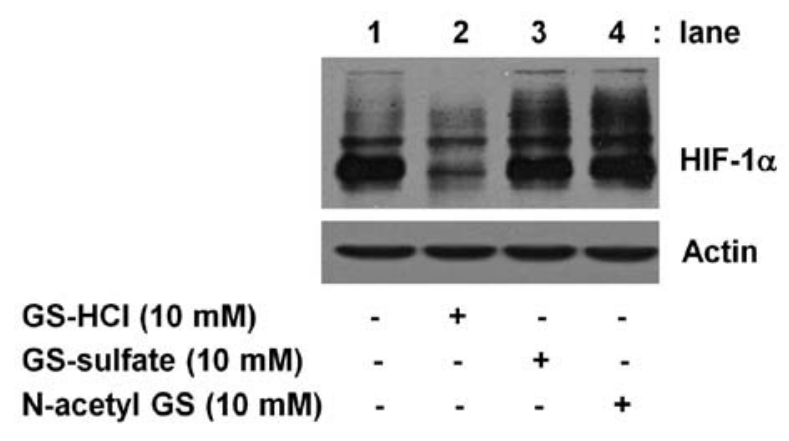

Figure 6. Comparison of the effect of GS-HCl, GS-sulfate or N-acetyl GS on expression of HIF-1 $\alpha$ protein in YD-8 cells. YD-8 cells were treated without or with GS-HCl $(10 \mathrm{mM}), \mathrm{GS}$-sulfate $(10 \mathrm{mM})$, other GS salt or N-acetyl GS $(10 \mathrm{mM})$, a GS derivative for $4 \mathrm{~h}$. Whole cell lysates were then prepared, and analyzed by western blot analysis. The experiments were carried out under normoxia. The image is a representative of three independent experiments.

YD-8 cells under normoxic condition (Fig. 1), indicating that expression of HIF-1 $\beta$ is controlled at the levels of transcription and translation. In this study, however, we show that long-term GS-HCl treatment inhibits expression of HIF-1 $\beta$ by transcriptional downregulation while short-term GS-HCl treatment does not influence expression of HIF-1 $\beta$ at protein and mRNA levels, which may further strengthen the specificity of shortterm $\mathrm{GS}-\mathrm{HCl}$ treatment to inhibit expression of HIF-1 $\alpha$ protein in YD-8 cells.

Previously, studies have demonstrated the importance of activities of a number of intracellular signaling proteins and/or translation-related proteins in normoxic upregulation of HIF-1 $\alpha$ protein in response to extracellular stimuli $(22,24-28)$. Among these, S6 is a ribosomal protein involved in translation (32). S6 is shown to be phosphorylated and activated by the action of an upstream protein kinase p70S6K (33). Moreover, there is evidence that PI3K/PKB and mTOR are upstream kinases 
responsible for S6K phosphorylation and activation (34). Of interest, there are studies demonstrating $\mathrm{GS}-\mathrm{HCl}$ regulation of S6K signaling pathway. For instance, it is shown that $24 \mathrm{~h}$ treatment with $\mathrm{GS}-\mathrm{HCl}(5 \mathrm{mM})$ inhibits the activity of S6K in DU145 prostate cancer cells and MDA-MB-231 breast cancer cells and the inhibition is important for GS-HCl-induced anti-proliferative effects on these cancer cells (9). The same group also has addressed that $10 \mathrm{~h}$ treatment with $\mathrm{GS}-\mathrm{HCl}$ (5 mM) inhibits S6K signaling pathway and importantly the inhibition is in part linked to inhibition of HIF-1 $\alpha$ at protein level in serum-treated DU145 cells (13). In the present study, we have shown that short-term $(2$ or $4 \mathrm{~h}$ ) treatment with $\mathrm{GS}-\mathrm{HCl}(10 \mathrm{mM})$ largely blocks phosphorylation of not only S6K but also S6 in YD-8 cells (Fig. 2A). However, as deduced from results of pharmacological inhibition studies herein that treatment with rapamycin, an mTOR/S6K/S6 that completely blocks S6 phosphorylation does not influence HIF-1 $\alpha$ protein expression in YD-8 cells (Fig. 2B), it appears that no link exists between $\mathrm{HIF}-1 \alpha$ protein downregulation and inhibition of mTOR/S6K/S6 signaling pathway in YD-8 cells in response to short-term $\mathrm{GS}-\mathrm{HCl}$ exposure. eIF-2 $\alpha$ is another translational regulatory protein (35). It has been shown that phosphorylation (on Serine 51) of eIF-2 $\alpha$ by stress kinases, such as protein kinase $\mathrm{R}$, leads to its inactivation and inhibition of global translation (36). There are previous studies stating that GS inhibits protein, mRNA, DNA synthesis in mouse leukemic cells L5178Y, which may contribute to its antitumor effect $(6,7)$. However, it has been shown that short-term $(2 \mathrm{~h})$ treatment with GS-HCl $(2$ or $5 \mathrm{mM})$ does not affect global protein synthesis in DU145 cells (13). In this study, we demonstrated that short-term (2 or 4 h) GS-HCl treatment increased phosphorylated forms of eIF- $2 \alpha$ in YD-8 cells (Fig. 2A), raising the possibility that short-term $\mathrm{GS}-\mathrm{HCl}$ treatment may inactivate eIF-2 $\alpha$ leading to inhibition of global translation in the cells. However, the present findings that short-term GS-HCl treatment does not affect expression of other proteins, herein HIF- $1 \beta$ and actin, in YD- 8 cells (Fig. 1C and D), and there is no difference of the amounts of total protein in control or GS-HCl $(4 \mathrm{~h})$-treated YD-8 cells (data not shown) suggest that though there is eIF-2 $\alpha$ inactivation, short-term GS-HCl treatment does not induce inhibition of global translation and HIF-1 $\alpha$ protein downregulation seems to be not a part of inhibition of global translation, but a selective event triggered by short-term exposure of this amino sugar in YD-8 cells.

Increasing evidence suggests that degradation of HIF-1 $\alpha$ at protein level is largely associated with the $26 \mathrm{~S}$ proteasomemediated proteolytic pathways $(16,17,19,31,37)$. However, the lysosome-mediated degradation of HIF-1 $\alpha$ protein also has been proposed (38). Interestingly, there is a previous study implicating the $26 \mathrm{~S}$ proteasome-independent mechanism of downregulation of HIF-1 $\alpha$ protein induced by $\mathrm{GS}-\mathrm{HCl}$ in DU145 cells (13). In this study, we demonstrate that treatment with MG132 (Fig. 3A, lane 5), but not CQ (lane 6), blocks the repressive effect of short-term $\mathrm{GS}-\mathrm{HCl}$ treatment on expression of HIF-1 $\alpha$ protein in YD-8 cells (lane 4). However, considering that single treatment with MG132 strongly upregulates expression of HIF-1 $\alpha$ at protein level in YD-8 cells (lane 2), it is likely that $\mathrm{HIF}-1 \alpha$ protein downregulation induced by short-term GS-HCl treatment in YD-8 cells herein is the
$26 \mathrm{~S}$ proteasome and lysosome-independent. Several lines of evidence indicate that HIF-1 $\alpha$ protein is very labile and its half-life is less than an hour $(16,25)$. In agreement with it, the present study demonstrates that when translation is blocked by $\mathrm{CHX}, \mathrm{HIF}-1 \alpha$ protein induced by serum in YD- 8 cells under normoxia is rapidly destabilized regardless of presence or absence of GS-HCl, which may further imply that HIF-1 $\alpha$ protein downregulation induced by short-term $\mathrm{GS}-\mathrm{HCl}$ treatment in YD-8 cells is not mediated through alteration of HIF-1 $\alpha$ protein stability.

It has been introduced that glucose is an inducer of HIF-1 $\alpha$ expression (accumulation) in human gliomas and other cancer cell lines under normoxia, which requires the metabolism of glucose to pyruvate that prevents the aerobic degradation of HIF-1 $\alpha$ protein (39). Furthermore, the same research group has reported that iodoacetate, an inhibitor of glyceraldehyde3-phosphate dehydrogenase completely blocks the ability of glucose to stimulate aerobic HIF- $1 \alpha$ protein accumulation and the replacement of glucose with the citric acid cycle intermediates, such as citrate or 2-oxoglutarate, does not stimulate it. GS is a glucose deprivation mimetic and has been shown to inhibit glycolysis $(39,40)$. It also has been demonstrated that both glucose and GS utilize the same glucose transporter system for import into the cells $(41,42)$, and GS, through inhibition of glucose transporter, interferes with cellular glucose uptake (43). With this in mind, it is assumed that short-term GS-HCl exposure into YD-8 cells may hinder glucose uptake, inhibit glycolysis, and/or produce less (or no) glucose metabolites. In this study, we have shown that HIF-1 $\alpha$ protein downregulation by short-term GS-HCl treatment in YD-8 cells is blunted by exogenous administration of citrate or 2-oxoglutarate, but not pyruvate or lactate (Fig. 4). These results strongly suggest a link between HIF-1 $\alpha$ protein downregulation and interference of glucose metabolism pathway (particularly production of the citric acid cycle intermediates) in YD-8 cells in response to short-term $\mathrm{GS}-\mathrm{HCl}$ treatment. An interesting finding in the present study is the specificity of $\mathrm{GS}-\mathrm{HCl}$ in downregulating HIF-1 $\alpha$ at protein level in YD-8 cells, as deduced from that short-term treatment with GS-sulfate or N-acetyl GS does not influence expression of HIF-1 $\alpha$ protein in YD-8 cells (Fig. 5).

Because established cancer cell lines are poor indicators of the tumor biology, the pathophysiological relevance of the present finings is unclear at present. Previously, studies have shown that HIF-1 $\alpha$ expression is linked to tumor promotion in human OSCC (44) and correlates with the growth and adhesion in human OSCC cells (45). We and others have also recently demonstrated that HIF-1 $\alpha$ protein is highly expressed in YD-8 tongue cancer cells (12) and DU145 prostate cancer cells (13), and long-term $(24,48$ or 72 h) GS-HCl treatment inhibits proliferation, decreases survival and/or induces apoptosis in YD-8, DU145 and MDA-MB231 breast cancer cells $(9,12,13)$. In view of this, the present study may have importance to address that i) downregulation of HIF-1 $\alpha$ protein induced by short-term GS-HCl treatment may facilitate anti-proliferative, antisurvival and pro-apoptotic effects on YD-8 cells triggered by long-term $\mathrm{GS}-\mathrm{HCl}$ treatment and ii) short-term treatment with $\mathrm{GS}-\mathrm{HCl}$ alone and/or in combination with other anticancer therapeutics may be useful against OSCC and other malignances in which aberrant expression of HIF-1 $\alpha$ protein plays an oncogenic role and/or confers drug resistance. 
Collectively, our data demonstrate for the first time that short-term GS-HCl treatment specifically reduces HIF-1 $\alpha$ at protein level in YD-8 cells, and the reduction is at least in part associated with interference of the citric acid cycle and/or less production of the citric acid cycle metabolites.

\section{Acknowledgements}

We greatly thank Professor Ki-Young Nam for proofreading this manuscript.

\section{References}

1. Hua J, Suguro S, Hirano S, Sakamoto K and Nagaoka I: Preventive actions of a high dose of glucosamine on adjuvant arthritis in rats. Inflamm Res 54: 127-132, 2005.

2. Reginster JY, Deroisy R, Rovati LC, Lee RL, Lejeune E, Bruyere O, Giacovelli G, Henrotin Y, Dacre JE and Gossett C: Long-term effects of glucosamine sulphate on osteoarthritis progression: a randomized, placebo-controlled clinical trial. Lancet 357: 251-256, 2001.

3. Largo R, Alvarez-Soria MA, Diez-Ortego I, Calvo E, Sanchez-Pernaute O, Egido J and Herrero-Beaumont G Glucosamine inhibits IL-1beta-induced NFkappaB activation in human osteoarthritic chondrocytes. Osteoarthritis Cartilage 11: 290-298, 2003.

4. Nakamura M, Shibakawa A, Tanaka M, Kato T and Nishioka K Effects of glucosamine hydrochloride on the production of prostaglandin E2, nitric oxide and metalloproteases by chondrocytes and synoviocytes in osteoarthritis. Clin Exp Rheumatol 22: 293-299, 2004

5. Quastel JH and Cantero A: Inhibition of tumor growth by D-glucosamine. Nature 171: 252-254, 1953.

6. Bekesi JG and Winzler RJ: Inhibitory effects of D-glucosamine on the growth of Walker 256 carcinosarcoma and on protein, RNA, and DNA synthesis. Cancer Res 30: 2905-2912, 1970.

7. Bosmann HB: Inhibition of protein, glycoprotein, ribonucleic acid and deoxyribonucleic acid synthesis by D-glucosamine and other sugars in mouse leukemic cells L5178Y and selective inhibition in SV-3T3 compared with 3T3 cells. Biochim Biophys Acta 240: 74-93, 1970.

8. Wang Z, Liang R, Huang GS, Piao Y, Zhang YQ, Wang AQ, Dong BX, Feng JL, Yang GR and Guo Y: Glucosamine sulfateinduced apoptosis in chronic myelogenous leukemia K562 cells is associated with translocation of cathepsin D and downregulation of Bcl-xL. Apoptosis 11: 1851-1860, 2006.

9. Oh HJ, Lee JS, Song DK, Shin DH, Jang BC, Suh SI, Park JW, Suh MH and Baek WK: D-glucosamine inhibits proliferation of human cancer cells through inhibition of p70S6K. Biochem Biophys Res Commun 360: 840-845, 2007.

10. Chesnokov V, Sun C and Itakura K: Glucosamine suppresses proliferation of human prostate carcinoma DU145 cells through inhibition of STAT3 signaling. Cancer Cell Int 9: 25, 2009.

11. Hwang MS and Baek WK: Glucosamine induces autophagic cell death through the stimulation of ER stress in human glioma cancer cells. Biochem Biophys Res Commun 399: 111-116, 2010.

12. Jung CW, Jo JR, Lee SH, Park YK, Jung NK, Song DK, Bae J, Nam KY, Ha JS, Park IS, Park GY, Jang BC and Park JW: Anti-cancer properties of glucosamine-hydrochloride in YD-8 human oral cancer cells: Induction of the caspase-dependent apoptosis and down-regulation of HIF-1 $\alpha$. Toxicol In Vitro 26 42-50, 2012.

13. Park JY, Park JW, Suh SI and Baek WK: D-glucosamine down-regulates HIF-lalpha through inhibition of protein translation in DU145 prostate cancer cells. Biochem Biophys Res Commun 382: 96-101, 2009.

14. Wang GL, Jiang BH, Rue EA and Semenza GL: Hypoxia-inducible factor 1 is a basic-helix-loop-helix-PAS heterodimer regulated by cellular $\mathrm{O}_{2}$ tension. Proc Natl Acad Sci USA 92: 5510-5514, 1995

15. Semenza GL: Hypoxia-inducible factor 1: master regulator of $\mathrm{O}_{2}$ homeostasis. Curr Opin Genet Dev 8: 588-594, 1998.

16. Salceda $\mathrm{S}$ and Caro J: Hypoxia-inducible factor 1 alpha (HIF-1alpha) protein is rapidly degraded by the ubiquitinproteasome system under normoxic conditions. Its stabilization by hypoxia depends on redox-induced chages. J Biol Chem 272: 22642-22647, 1997.
17. Huang LE, Gu J, Schau M and Bunn HF: Regulation of hypoxia-inducible factorlalpha is mediated by an $\mathrm{O}_{2}$-dependent degradation domain via the ubiquitin proteasome pathway. Proc Natl Acad Sci USA 95: 7987-7992, 1998.

18. Tanimoto K, Makino Y, Pereira T and Poellinger L: Mechanism of regulation of the hypoxia-inducible factor-1 alpha by the von Hippel-Lindau tumor suppressor protein. EMBO J 19: 4298-4309, 2000

19. Ivan M, Kondo K, Yang H, Kim W, Valiando J, Ohh M, Salic A, Asara JM, Lane WS and Kaelin Jr WG: HIFalpha targeted for VHL-mediated destruction by proline hydroxylation: implications for $\mathrm{O}_{2}$ sensing. Science 292: 464-468, 2001.

20. Qian D, Lin HY, Wang HM, Zhang X, Liu DL, Li QL and Zhu C: Normoxic induction of the hypoxic-inducible factor-1 alpha by interleukin-1 beta involves the extracellular signalregulated kinase $1 / 2$ pathway in normal human cytotrophoblast cells. Biol Reprod 70: 1822-1827, 2004.

21. Doronzo G, Russo I, Mattiello L, Riganti C, Anfossi G and Trovati M: Insulin activates hypoxia-inducible factor-1alpha in human and rat vascular smooth muscle cells via phosphatidylinositol-3 kinase and mitogen-activated protein kinase pathways: impairment in insulin resistance owing to defects in insulin signaling. Diabetologia 49: 1049-1063, 2006.

22. Shin HJ, Choi MS, Ryoo NH, Nam KY, Park GY, Bae JH, Suh SI, Baek WK, Park JW and Jang BC: Manganese-mediated upregulation of HIF-1alpha protein in Hep2 human laryngeal epithelial cells via activation of the family of MAPKs. Toxicol In Vitro 24: 1208-1214, 2010.

23. Leung $\mathrm{KW}$, Ng HM, Tang MK, Wong CC, Wong RN and Wong AS: Ginsenoside-Rg1 mediates a hypoxia-independent upregulation of hypoxia-inducible factor- $1 \alpha$ to promote angiogenesis. Angiogenesis 14: 515-522, 2011.

24. Yen ML, Su JL, Chien CL, Tseng KW, Yang CY, Chen WF, Chang CC and Kuo ML: Diosgenin induces hypoxia-inducible factor-1 activation and angiogenesis through estrogen receptor-related phosphatidylinositol 3-kinase/Akt and p38 mitogen-activated protein kinase pathways in osteoblasts. Mol Pharmacol 68: 1061-1073, 2005.

25. Jang BC: The fruit juice of Morinda citrifolia (noni) downregulates HIF-1 $\alpha$ protein expression through inhibition of PKB, ERK-1/2, JNK-1 and S6 in manganese-stimulated A549 human lung cancer cells. Int J Mol Med 29: 499-504, 2012.

26. Tamura K, Yoshie M, Miyajima E, Kano M and Tachikawa E: Stathmin regulates hypoxia-inducible factor- $1 \alpha$ expression through the mammalian target of rapamycin pathway in ovarian clear cell adenocarcinoma. ISRN Pharmacol 30: 279593, 2013.

27. Xie SR, Wang Y, Liu CW, Luo K and Cai YQ: Liquiritigenin inhibits serum-induced HIF-1 $\alpha$ and VEGF expression via the AKT/mTOR-p70S6K signalling pathway in HeLa cells. Phytother Res 26: 1133-1141, 2012.

28. Jeong JH, Jeong YJ, Cho HJ, Shin JM, Kang JH, Park KK, Park YY, Chung IK, Chang HW and Magae J: Ascochlorin inhibits growth factor-induced HIF- $1 \alpha$ activation and tumor-angiogenesis through the suppression of EGFR/ ERK/p70S6K signaling pathway in human cervical carcinoma cells. J Cell Biochem 113: 1302-1313, 2012.

29. Laplante M and Sabatini DM: mTOR signaling in growth control and disease. Cell 149: 274-293, 2012.

30. Epstein AC, Gleadle JM, McNeill LA, Hewitson KS, O'Rourke J, Mole DR, Mukherji M, Metzen E, Wilson GD, Dhanda A, Tian YM, Masson N, Hamilton DL, Jaakkola P, Barstead R, Hodgkin J, Maxwell PH, Pugh CW, Schofield CJ and Ratcliffe PJ: C. elegans EGL-9 and mammalian homologs define a family of dioxygenases that regulate HIF by prolyl hydroxylation. Cell 107: 43-54, 2001.

31. Maxwell PH, Wiesener MS, Chang GW, Clifford SC, Vaux EC, Cockman ME, Wykoff CC, Pugh CW, Maher ER and Ratcliffe PJ: The tumour suppressor protein VHL targets hypoxia-inducible factors for oxygen-dependent proteolysis. Nature 399: 271-275, 1999

32. Meyuhas O: Physiological roles of ribosomal protein S6: one of its kind. Int Rev Cell Mol Biol 268: 1-37, 2008.

33. Berven LA and Crouch MF: Cellular function of p70S6K: a role in regulating cell motility. Immunol Cell Biol 78: 447-451, 2000.

34. Fang CX, Yang X, Sreejayan N and Ren J: Acetaldehyde promotes rapamycin-dependent activation of p70(S6K) and glucose uptake despite inhibition of Akt and mTOR in dopaminergic SH-SY5Y human neuroblastoma cells. Exp Neurol 203: 196-204, 2007. 
35. Baird TD and Wek RC: Eukaryotic initiation factor 2 phosphorylation and translational control in metabolism. Adv Nutr 3: 307-321, 2012.

36. De Haro C, Méndez R and Santoyo J: The eIF-2alpha kinases and the control of protein synthesis. FASEB J 10: 1378-1387, 1996.

37. Maynard MA and Ohh M: Von Hippel-Lindau tumor suppressor protein and hypoxia-inducible factor in kidney cancer. Am J Nephrol 24: 1-13, 2004.

38. Hubbi ME, Hu H, Kshitiz Ahmed I, Levchenko A and Semenza GL: Chaperone-mediated autophagy targets hypoxiainducible factor- $1 \alpha$ (HIF-1 $\alpha$ ) for lysosomal degradation. J Biol Chem 288: 10703-10714, 2013.

39. Tesoriere G, Vento R and Calvaruso G: Inhibitory effect of D-glucosamine on glycolysis in bovine retina. Biochim Biophys Acta 385: 58-67, 1975.

40. Zhang J, Zhao M and Peng S: Synthesis of mimetic peptides containing glucosamine. Carbohydr Res 346: 1997-2003, 2011.
41. Oguchi M, Miyatake Y, Ayabe J and Akamatsu N: Phosphorylation of D-glucosamine by rat liver glucokinase. J Biochem 77: 1117-1121, 1975.

42. Uldry M, Ibberson M, Hosokawa M and Thorens B: GLUT2 is a high affinity glucosamine transporter. FEBS Lett 524: 199-203, 2002.

43. Kim YK, Park JH, Park SH, Lim B, Baek WK, Suh SI, Lim JG, Ryu GR and Song DK: Protective role of glucagon-like peptide-1 against glucosamine induced cytotoxicity in pancreatic beta cells. Cell Physiol Biochem 25: 211-220, 2010.

44. Brennan PA, Mackenzie N and Quintero M: Hypoxia-inducible factor 1alpha in oral cancer. J Oral Pathol Med 34: 385-389, 2005.

45. Song Y, Wang W, Qu X and Sun S: Effects of hypoxia inducible factor-1 alpha (HIF-1alpha) on the growth and adhesion in tongue squamous cell carcinoma cells. Indian J Med Res 129: 154-163, 2009. 